\title{
Chrysanthemum Production in Composted and Noncomposted Organic Waste Substrates Fertilized with Nitrogen at Two Rates Using Surface and Subirrigation
}

\author{
Michele Krucker, Rita L. Hummel ${ }^{1}$, and Craig Cogger \\ Washington State University Puyallup Research and Extension Center, 2606 \\ West Pioneer, Puyallup, WA 98371
}

Additional index words. Chrysanthemum $\times$ morifolium, biosolids, peat substitute, capillary mat, dairy manure fiber, anaerobic digestion

\begin{abstract}
As nursery and greenhouse growers adopt more sustainable production practices, interest has grown in local, recycled organic materials (ROM) as partial or complete substitutes for peat in container substrates. Chrysanthemum $\times$ morifolium Ramat. 'Shasta' was grown in substrates formulated from ROM: 1) 100\% Groco, an anaerobically digested biosolids composted with sawdust; 2) $100 \%$ Tagro, a thermophilically digested class A biosolid mixed with sawdust and sand; 3 ) $100 \%$ dairy compost, the solids screened from dairy manure slurry and then composted; 4) $100 \%$ dairy fiber, the solids fraction from an anaerobic dairy manure digester; 5) 50\% Groco:50\% douglas-fir bark (mixed by volume); 6) $50 \%$ Tagro:50\% bark; 7) $50 \%$ dairy compost:50\% bark; 8) $\mathbf{5 0 \%}$ dairy fiber:50\% bark; and 9) the control, a commercial peat-perlite mixture. Soluble fertilizer [200 mg. $\mathrm{L}^{-1}$ nitrogen $\left.(\mathrm{N})\right]$ was applied every second day (high $N$ ) or every fourth day (low $\mathrm{N}$ ). Water was applied through capillary mat subirrigation or overhead sprinkler surface irrigation. Surface irrigation and high N produced shoot dry weight, shoot growth index (SGI), quality, and flower bud counts similar to controls in all ROMs but Groco. Groco SGI was similar to the control but the other parameters were lower. Surfaceirrigated, low N shoot dry weight, SGI, and flower buds in all ROM equaled or exceeded the control and quality was similar to or better than controls in all but dairy compost:bark. Subirrigated and high $\mathrm{N}$ substrate comparisons indicated that growth, quality, and flower bud measurements were similar to the control except for Groco in which performance was reduced. Low $\mathrm{N}$ rate subirrigation produced dry weight, SGI, quality, and flower buds similar to or better than the control in all but the Groco and dairy compost:bark substrates. The generally inferior performance in Groco is likely the result of its low water-holding capacity. In substrates with higher available N (Groco, Tagro, Tagro:bark, and dairy fiber), plant growth parameters generally did not respond to doubling the applied $\mathrm{N}$; in the other substrates, including the control, growth generally increased in response to additional $N$. Measured differences in leaf color across treatments were not large. Root growth of plants in the experimental substrates was similar to the control in both irrigation systems. Substrate effects on leachate nitrate- $\mathrm{N}$ were small and inconsistent. When properly constituted, biosolids and dairy manure can be used as substrates under reduced fertilization with both surface and subirrigation systems.
\end{abstract}

Sphagnum peat has been the standard base component for most container growing substrates in the United States since the 1950s. It is an ideal container substrate because it has low bulk density, high water-holding capacity,

Received for publication 21 June 2010. Accepted for publication 9 Sept. 2010.

Funding for this project was provided by the Northwest Biosolids Management Association and the Agricultural Research Center at Washington State University through Hatch Projects 3755 and 0722 .

We thank Bob Riley, Susan Smith, Andy Bary, and Liz Myhre for their technical assistance and Yoder Brothers, Inc. for the chrysanthemum cuttings.

${ }^{1}$ To whom reprint requests should be addressed; e-mail hummelrl@wsu.edu. good aeration porosity, low soluble salts, acceptable $\mathrm{pH}$, and high uniformity across batches (Schmilewski, 1983; Stamps and Evans, 1999). As nursery and greenhouse growers seek to adopt more environmentally and economically sustainable practices, interest has grown in the use of local, recycled organic materials as partial or complete substitutes for peat in container substrates (Fitzpatrick, 2001; Raviv, 2005). Because these materials have typically entered the waste stream, their use as container substrates reduces solid waste production and the subsequent need for disposal.

Alternative components include various composted materials (Carlile, 2008; Corti et al., 1998) using feedstocks such as yard debris and pruning waste, animal manures, biosolids, agricultural green waste, woody debris, municipal solid waste, and food waste.
In general, substrates made from these materials have greater bulk density, soluble salts, and $\mathrm{pH}$; lower porosity and available water capacity; and less uniformity than peat-based substrates (Corti et al., 1998). Despite these shortcomings, numerous studies have shown that container substrates with acceptable quality can be made using composts, supplying nutrients and producing plants of equivalent and sometimes better growth and quality compared with standard substrates (Bugbee, 2002; Clark and Cavigelli, 2005; EstévezSchwarz et al., 2009; Grigatti et al., 2007; Hummel et al., 2000, 2001; Tittarelli et al., 2009). High salt content and lack of uniformity frequently have been the greatest problems to overcome in developing alternative container substrates (Bugbee, 2002; OzoresHampton et al., 1999).

Bark, another component of container substrates often used at rates as high as $60 \%$ to $100 \%$ by volume, is decreasing in availability and rising in cost (Buamscha et al., 2007; $\mathrm{Lu}$ et al., 2006). The demand for sustainable alternatives to bark has prompted research to develop substrates composed of whole pine trees (Fain et al., 2008; Jackson and Wright, 2009) and clean chip residual (Boyer et al., 2009). Other uncomposted materials may also have potential as inexpensive and sustainable peat substitutes (Ingelmo et al., 1998), but many of these materials have had little study. Some uncomposted recycled organic materials currently in use or with potential as substrate components include coir (Stamps and Evans, 1999), poultry feather fiber (Evans, 2004), rice hulls (Evans and Gachukia, 2004), and a noncomposted residential refuse (Kahtz and Gawel, 2004).

Reducing water and fertilizer use and managing leachate are also key to sustainable container production systems (Biernbaum, 1992; Uva et al., 1998). Research has demonstrated the efficiencies of subirrigation with recirculation in reducing water, fertilizer, and labor inputs while maintaining plant growth and quality (Argo and Biernbaum, 1995; KlockMoore and Broschat, 1999; Molitor, 1990; Morvant et al., 1998, 2001; Neal and Henley, 1992; Uva et al., 1998). Subirrigation relies on water uptake through capillary action, and substrates suitable for subirrigation systems must readily absorb water by capillarity (Reed, 1996). Gabriëls et al. (1986) stress the importance of substrate physical parameters, especially aeration, in subirrigation systems. Most of the research on subirrigation systems has been done using substrates with peatmoss as a primary component. Incorporation of recycled organic materials into sustainable container production systems requires testing their efficacy as substrates for subirrigated crops.

This project compares a range of locally available peat substitutes for greenhouse production of chrysanthemum fertilized at two $\mathrm{N}$ rates using conventional overhead irrigation and a capillary mat subirrigation system. Alternative substrates include biosolids compost, an uncomposted class A biosolids (U.S. Environmental Protection Agency, 1994) blend, dairy manure compost, and solids from an 
anaerobic dairy manure digester. Our objectives were to 1) determine the growth and quality response of chrysanthemum grown at two $\mathrm{N}$ rates to the different substrates under overhead and subirrigation systems; and 2) determine the effect of the substrates and $\mathrm{N}$ on leachate water quality under the two irrigation systems.

\section{Materials and Methods}

Uniform rooted cuttings of chrysanthemum, Chrysanthemum $\times$ morifolium Ramat. 'Shasta', from Yoder Brothers, Inc., were transplanted into $0.7-\mathrm{L}$ square containers $10 \mathrm{~cm}$ tall with a $10-\mathrm{cm}$ wide top on 12 Sept. 2002. The containers were filled with the following experimental growth substrates: 100\% Groco, 100\% Tagro, $100 \%$ dairy manure compost (dairy compost), $100 \%$ digested dairy manure fiber (dairy fiber), $50 \%$ Groco:50\% fresh douglasfir bark (mixed by volume), 50\% Tagro:50\% bark, $50 \%$ dairy compost: $50 \%$ bark, and $50 \%$ dairy fiber:50\% bark. A commercially formulated, bagged peat-perlite mixture (Fisons Sunshine Mix \#2; Sun Gro Horticulture, Inc., Bellevue, WA; $70 \%$ to $80 \%$ sphagnum peatmoss, perlite, dolomitic limestone, and gypsum, no nutrients added) was used as an industry standard control (control). Groco is a biosolids compost from King County, WA, and consists of anaerobically digested, class B biosolids (U.S. Environmental Protection Agency, 1994) blended with sawdust at a volume of $3: 1$ and composted for the necessary time to remove the remaining pathogens. Tagro is a biosolids product from the Tacoma, WA, Central Wastewater Treatment Plant. It consists of a thermophilically digested class A biosolids "cake" that is mixed with sawdust and sand at a volume of $2: 1: 1$. Dairy compost consisted of the solids screened from dairy manure slurry and then composted in turned piles on the dairy to remove pathogens. Dairy fiber was the solids fraction from an anaerobic digester used to capture methane gas from dairy manure.

Tests were conducted on quadruplicate samples of these substrates to measure initial pH (Hanna pH meter, Model EN 50081-1; Portugal), electrical conductivity (EC; Orion EC meter, Model 128; MS), water-holding capacity (WHC), aeration porosity (AP), and nitrate-N levels $\left(\mathrm{NO}_{3}-\mathrm{N}\right.$; Hach One Laboratory $\mathrm{pH} / \mathrm{ISE}$ meter, Model 44700; CO; with nitrate electrode) (Table 1). Substrate $\mathrm{pH}, \mathrm{EC}$, and $\mathrm{NO}_{3}-\mathrm{N}$ samples were measured using the 1:5 method (Thompson et al., 2001). WHC and AP were determined by following the volume measurement technique described by Ingram et al. (1990).

Dairy manure fiber had an initial EC average above the recommended range (Table 1) so it was leached with a volume of water equivalent to four times the volume of the substrate. Chen et al. (1983) and Inbar et al. (1985) also found high EC in digested dairy manure fiber. After leaching, the EC, nitrate, and $\mathrm{pH}$ levels for dairy fiber and dairy fiber: bark were in the same range as the other substrates (Table 1).
Duplicate substrate samples were dried, ground, and sent to the University of Nebraska analytical laboratory for analysis of total carbon (C), total $\mathrm{N}$, ammonium $\mathrm{N}$, nitrate- $\mathrm{N}$, phosphorus, potassium, and $\mathrm{C}: \mathrm{N}$ ratio (Table 2). Total $\mathrm{N}$ and $\mathrm{C}$ were determined using a combustion analyzer equipped with an infrared detector (LECO Instruments, St. Joseph, $\mathrm{MI})$. Ammonium and nitrate-N were extracted with $2 \mathrm{M} \mathrm{KCl}$ and then analyzed by the salicylate method for ammonium by cadmium reduction for nitrate. Phosphorus and potassium were analyzed by inductively coupled plasma spectroscopy following a strong acid digestion. Additional samples were shaken for 3 min on a sieve shaker through U.S. Standard Tyler screens to determine particle size distribution (Table 3 ).

Before potting, all substrates were amended with Scotts Micromax micronutrient mix at a rate of $1038 \mathrm{~g} \cdot \mathrm{m}^{-3}$. Plants were manually watered immediately after transplant and then randomly assigned to one of two irrigation systems: subirrigation or overhead irrigation. Two $1.5 \times 6.7-\mathrm{m}$ greenhouse benches were equipped with Bottom $\mathrm{Up}^{\mathrm{TM}}$ subirrigation mats (Irrigation and Water Technologies, Rouse Hill, NSW, Australia). Overhead irrigation was applied on two equivalent benches with Vari Mister MV sprinkler heads (DripWorks, Willits, CA) attached through $30.5-\mathrm{cm}$ risers (Olson Ultra-Jet PE; Olson Irrigation Systems, Santee, CA) to DNPC6 Woodpecker PC (Netafim) pressure-compensating emitters (DripWorks) inserted at $30.5-\mathrm{cm}$ intervals in 1.3-cm mainlines attached to the greenhouse benches. Overhead-irrigated plants were inspected and pot weights judged for signs of water depletion and were typically irrigated daily to produce a leaching fraction in the range 0.1 to 0.2 . Frequency of irrigations was the same for both systems. The Bottom Up ${ }^{T M}$ mats combined the properties of ebb and flow with capillary mat subirrigation and plants were kept wet for $1 \mathrm{~h}$ before the mats drained.

Four d after transplanting, all plants were fertilized with a $200 \mathrm{mg} \cdot \mathrm{L}^{-1} \mathrm{~N}, 100 \mathrm{mg} \cdot \mathrm{L}^{-1}$ phosphorus $(\mathrm{P})$, and $200 \mathrm{mg} \cdot \mathrm{L}^{-1}$ potassium (K) solution. Thereafter $\mathrm{N}$ fertilizer solutions were applied at two $\mathrm{N}$ rates, either $200 \mathrm{mg} \cdot \mathrm{L}^{-1}$ $\mathrm{N}$ every other day (high $\mathrm{N}$ rate) or $200 \mathrm{mg} \cdot \mathrm{L}^{-1}$ $\mathrm{N}$ every $4 \mathrm{~d}$ (low $\mathrm{N}$ rate). To ensure uniformity of $\mathrm{P}$ and $\mathrm{K}$ application, a second solution containing $100 \mathrm{mg} \cdot \mathrm{L}^{-1} \mathrm{P}$ and $200 \mathrm{mg} \cdot \mathrm{L}^{-1} \mathrm{~K}$ but no $\mathrm{N}$ was made and applied to the low $\mathrm{N}$ plants on the days when the solution containing $\mathrm{N}$ was applied only to the high $\mathrm{N}$ plants. Thus, all plants received the same amount of $\mathrm{P}$ and $\mathrm{K}$; only the $\mathrm{N}$ rate varied. These fertilizer solutions were prepared fresh before each application using combinations of ammonium nitrate (EM Science, Germany), potassium sulfate (J.T. Baker Chemical Co., Phillipsburg, NJ), and potassium phosphate monobasic (EM Science, Darmstadt). The water used to mix the fertilizer solutions had a $\mathrm{pH}$ of 6.9 and an $\mathrm{EC}$ of $0.2 \mathrm{dS} \cdot \mathrm{m}^{-1}$. To correspond with the irrigation method used, overhead-irrigated plants were fertilized by hand application of $60 \mathrm{~mL}$ of solution to the surface of the substrate. This

Table 1. Initial aeration porosity (AP), water-holding capacity (WHC), pH, electrical conductivity (EC) and nitrate-nitrogen $\left(\mathrm{NO}_{3}-\mathrm{N}\right)$ levels of the experimental growth substrates. ${ }^{\mathrm{z}}$

\begin{tabular}{|c|c|c|c|c|c|}
\hline Substrates & $\mathrm{AP}(\%)$ & WHC (\%) & $\mathrm{pH}$ & $\mathrm{EC}\left(\mathrm{dS} \cdot \mathrm{m}^{-1}\right)$ & $\mathrm{NO}_{3}-\mathrm{N}\left(\mathrm{mg} \cdot \mathrm{L}^{-1}\right)$ \\
\hline Bark & 15 & 38 & 5 & 1.1 & 5 \\
\hline Dairy compost & 27 & 29 & 7.6 & 3.6 & 294 \\
\hline Dairy compost:bark & 19 & 40 & 6.4 & 2.1 & 133 \\
\hline Dairy fiber (pre-leach ${ }^{y}$ ) & 14 & 37 & 7.7 & 8.3 & 1060 \\
\hline Dairy fiber (post-leach ${ }^{\mathrm{x}}$ ) & $-^{w}$ & - & 7.8 & 3.6 & 137 \\
\hline Dairy fiber:bark (pre-leach) & 15 & 41 & 6.9 & 5.4 & 690 \\
\hline Dairy fiber:bark (post-leach) & - & - & 6.7 & 2.3 & 43 \\
\hline Groco & 25 & 19 & 6.1 & 2.1 & 204 \\
\hline Groco:bark & 21 & 40 & 5.7 & 1.5 & 89 \\
\hline Tagro & 22 & 29 & 6.2 & 1.3 & 88 \\
\hline Tagro:bark & 17 & 39 & 6.1 & 1.4 & 51 \\
\hline Peat-perlite control & 16 & 51 & 6.2 & 1.0 & 19 \\
\hline
\end{tabular}

${ }^{\mathrm{z}}$ The 1:5 method was used to determine $\mathrm{pH}, \mathrm{EC}$, and $\mathrm{NO}_{3}$ levels.

y Dairy fiber as obtained from the source.

${ }^{x}$ Dairy fiber after leaching with a volume of water equal to four times the substrate volume.

wNot measured after leaching.

Table 2. Nutrient analysis of the experimental growth substrates from the University of Nebraska commercial laboratory.

\begin{tabular}{|c|c|c|c|c|c|c|c|}
\hline Substrates & $\begin{array}{c}\mathrm{NO}_{3}-\mathrm{N} \\
\left(\mathrm{mg} \cdot \mathrm{kg}^{-1}\right)\end{array}$ & $\begin{array}{c}\mathrm{NH}_{4}-\mathrm{N} \\
\left(\mathrm{mg} \cdot \mathrm{kg}^{-1}\right)\end{array}$ & $\begin{array}{c}\text { Total } \\
\text { carbon }(\mathrm{C}) \\
\left(\mathrm{g} \cdot \mathrm{kg}^{-1}\right)\end{array}$ & $\begin{array}{c}\text { Total } \\
\text { nitrogen }(\mathrm{N}) \\
\left(\mathrm{g} \cdot \mathrm{kg}^{-1}\right)\end{array}$ & $\begin{array}{l}\mathrm{C}: \mathrm{N} \\
\text { Ratio }\end{array}$ & $\begin{array}{c}\text { Total } \\
\text { phosphorus } \\
\left(\mathrm{g} \cdot \mathrm{kg}^{-1}\right)\end{array}$ & $\begin{array}{c}\text { Total } \\
\text { potassium } \\
\left(\mathrm{g} \cdot \mathrm{kg}^{-1}\right)\end{array}$ \\
\hline Bark & 3 & 102 & 450 & 4 & 125 & 1 & 2 \\
\hline Dairy compost & 542 & 32 & 420 & 9 & 22 & 4 & 11 \\
\hline Dairy compost:bark & 162 & 47 & 450 & 8 & 60 & 1 & 5 \\
\hline Dairy fiber & 459 & 22 & 260 & 24 & 11 & 11 & 9 \\
\hline Dairy fiber:bark & 176 & 33 & 390 & 14 & 28 & 3 & 4 \\
\hline Groco & 407 & 1497 & 390 & 14 & 28 & 13 & 2 \\
\hline Groco:bark & 226 & 658 & 430 & 9 & 48 & 5 & 2 \\
\hline Tagro & 4 & 978 & 100 & 7 & 14 & 16 & 5 \\
\hline Tagro:bark & 12 & 900 & 240 & 7 & 35 & 5 & 3 \\
\hline Peat-perlite control & 27 & 84 & 290 & 7 & 45 & 0.1 & 9 \\
\hline
\end{tabular}




\begin{tabular}{|c|c|c|c|c|c|c|c|c|c|c|c|}
\hline \multirow[b]{2}{*}{$\begin{array}{l}\text { U.S. Standard } \\
\text { sieve no. }\end{array}$} & \multirow[b]{2}{*}{$\begin{array}{l}\text { Sieve opening } \\
(\mathrm{mm})\end{array}$} & \multicolumn{10}{|c|}{ Percent by wt } \\
\hline & & Bark & $\begin{array}{c}\text { Dairy } \\
\text { compost }\end{array}$ & $\begin{array}{c}\text { Dairy } \\
\text { compost:bark }\end{array}$ & $\begin{array}{l}\text { Dairy } \\
\text { fiber }\end{array}$ & $\begin{array}{c}\text { Dairy } \\
\text { fiber:bark }\end{array}$ & Groco & Groco:bark & Tagro & Tagro:bark & $\begin{array}{c}\text { Peat-perlite } \\
\text { control }\end{array}$ \\
\hline & $>12.7$ & 3 & 1 & 3 & 4 & 8 & 0 & 3 & 0 & 3 & 0 \\
\hline & $12.7-9.42$ & 7 & 3 & 7 & 2 & 8 & 0 & 6 & 0 & 0 & 2 \\
\hline 4 & $9.42-4.70$ & 19 & 8 & 16 & 22 & 20 & 5 & 13 & 3 & 12 & 9 \\
\hline 8 & $4.7-2.36$ & 18 & 22 & 19 & 31 & 20 & 21 & 20 & 12 & 16 & 18 \\
\hline 10 & $2.36-2.00$ & 4 & 8 & 5 & 7 & 5 & 9 & 6 & 5 & 5 & 4 \\
\hline 18 & $2.00-1.00$ & 12 & 26 & 15 & 17 & 15 & 39 & 24 & 21 & 18 & 14 \\
\hline 20 & $1.00-0.83$ & 3 & 8 & 4 & 3 & 3 & 8 & 6 & 7 & 5 & 5 \\
\hline 30 & $0.83-0.60$ & 6 & 9 & 7 & 4 & 7 & 10 & 7 & 13 & 10 & 8 \\
\hline 40 & $0.60-0.42$ & 6 & 6 & 6 & 3 & 5 & 4 & 5 & 15 & 11 & 7 \\
\hline Pan & $<0.42$ & 22 & 10 & 19 & 8 & 10 & 4 & 10 & 25 & 22 & 32 \\
\hline
\end{tabular}

typically produced a leaching fraction of 0.2 to 0.3 . Subirrigated plants were placed in shallow trays filled with fertilizer solution to a depth of $1.6 \mathrm{~cm}$ where they remained for $3 \mathrm{~h}$ before being returned to the subirrigation mat. Pots used in this study had four evenly spaced 0.6$\mathrm{cm}$ diameter round holes in the bottom and a $0.8-\mathrm{cm}$ wide by $1.2-\mathrm{cm}$ tall rectangular hole on each of the four sides. No additional irrigation was applied on the days plants were fertilized. Plants were fertilized until the flower buds showed petal color (Yoder Brothers, Inc., 1999).

High-pressure sodium lights provided $250 \mu \mathrm{mol} \cdot \mathrm{s}^{-1} \cdot \mathrm{m}^{-2}$ at canopy height when the plants were small to $260 \mu \mathrm{mol} \cdot \mathrm{s}^{-1} \cdot \mathrm{m}^{-2}$ as the plants grew (L1-190 Quantum Sensor; LICOR, Inc., Lincoln, NE). For the first 2 weeks, the plants were lighted from $2200 \mathrm{hr}$ until $0200 \mathrm{hr}$, then the short-day photoperiod was initiated. Temperatures were set at $22{ }^{\circ} \mathrm{C}$ for daytime and $17^{\circ} \mathrm{C}$ for night until flower buds were visible. Then temperatures were lowered to $18{ }^{\circ} \mathrm{C}$ during the day and $16{ }^{\circ} \mathrm{C}$ at night. When flower color was observed, temperatures were further lowered to $17^{\circ} \mathrm{C}$ during the day and $13{ }^{\circ} \mathrm{C}$ at night. To collect total growth data, the plants were not given vegetative or reproductive pinches.

Plant growth and quality measurements. Initial plant height and the narrowest and widest canopy widths were recorded at transplanting. Ten $\mathrm{d}$ after planting, stem height and the widest and narrowest canopy width were again measured. These measurements were taken every $7 \mathrm{~d}$ until the end of production. Height was determined as the distance from the substrate surface to the point just below the newest visible vegetative node or just below the flower bud, depending on the stage of development. A SGI was calculated from these data as follows: [(widest width + narrowest width) $/ 2+$ height] $/ 2$.

The Yoder Production Guide (Yoder Brothers, Inc., 1999) was used to determine when plants were ready for shipment to retailers. Leaf color and the number of visible flower buds were measured at this time. Color of the interveinal lamina of two fully expanded leaves from the stem midsection was determined quantitatively with a Minolta CR200b Chroma Meter (Minolta, Ramsay, NJ). The CIELAB coordinates, $\mathrm{L} * \mathrm{a} * \mathrm{~b} *$, were recorded and, following the advice of McGuire (1992), the chroma $\left(\mathrm{C}^{*}\right)$ and hue angle $\left(\mathrm{h}^{\circ}\right)$ were calculated using SAS (SAS 8.1; SAS Institute Inc., Cary, NC). $\mathrm{L}^{*}$ measures the lightness or value of the color from black (equal 0 ) to white (equal 100). $\mathrm{C}^{*}$ is the degree of color from gray (equal 0 ) to pure chromatic color and $\mathrm{h}^{\circ}$ is the attribute of color perceived (red, yellow, green, blue, or intermediate between adjacent pairs arranged on a $360^{\circ}$ color wheel).

At the end of greenhouse production, 9 weeks after transplanting, visual shoot quality of all plants was rated on a scale ranging from $5=$ a superior plant to $1=$ a poor-quality plant with a rating of 3 considered saleable. Root length and root density at the periphery of the root ball were rated on four randomly chosen replicates. Root length was rated from 4 (roots circling the bottom of the container) to 1 (roots growing half way to the container bottom). Root density was also rated on a 4 (solid root mass with little or no growing substrate visible at the periphery) to 1 (no roots visible at the periphery) scale. Finally, plants were cut at the substrate surface and the shoots were dried for $96 \mathrm{~h}$ at $60{ }^{\circ} \mathrm{C}$ in a forced-air oven then shoot dry weight was determined. Root systems were washed from the substrate and root dry weight was also measured.

Leachate measurements. Leachate was collected by the pour-through method, also known as the Virginia Tech Extraction Method (Wright, 1986) from alternating groups of four replicates per treatment at 2, 4, 6, and 8 weeks after transplanting. Samples were collected the third day after low $\mathrm{N}$ application, which was also $1 \mathrm{~d}$ after high $\mathrm{N}$ application. One $\mathrm{h}$ after irrigation, distilled water $(150 \mathrm{~mL})$ was added to the pots; the leachate was collected and analyzed for $\mathrm{pH}$, soluble salts, and $\mathrm{NO}_{3}-\mathrm{N}$.

Data analysis. For each irrigation method, there was a factorial treatment combination of nine growth substrates by two $\mathrm{N}$ fertilizer rates. There were eight replicate containers per treatment with one plant per container. Plants were arranged on greenhouse benches in a randomized complete block design. Data were subject to two-way analysis of variance (PROC GLM; SAS 8.1, SAS Institute Inc.). However, significant two-factor interactions necessitated the use of one-way analyses of variance to test the significance of growth substrates and fertilizer treatments for each irrigation method. Mean separations for the substrates were done with a Tukey's studentized range test. A Student's $t$ test was used to compare the high $\mathrm{N}$ with low $\mathrm{N}$ fertilizer treatments.

\section{Results and Discussion}

\section{Shoot growth, quality, and number of flower buds}

Surface irrigation. At the high $\mathrm{N}$ rate, shoot dry weight, SGI, quality, and flower bud counts of overhead-irrigated plants grown in the experimental substrates were similar to control plants in all but Groco and Tagro:bark (Table 4). Plants in Groco were similar in SGI but had smaller dry weight, lower quality, and fewer flower buds than plants in the control substrate. Plants grown in Tagro:bark had more flower buds but were otherwise similar to the controls. At the low $\mathrm{N}$ rate, shoot dry weight, SGI, and flower buds of plants in all recycled organic substrates were equivalent to or exceeded the peat-perlite control (Table 4). Plants in Tagro and Tagro:bark had greater shoot dry weight and more flower buds than the controls (Table 4). SGI of Tagro plants was also greater than the controls. Quality of overhead-irrigated low $\mathrm{N}$ plants grown in dairy fiber, Tagro, and Tagro:bark was higher than controls, whereas dairy compost:bark plants had lower quality. Plants in the other substrates had quality similar to the controls (Table 4).

When fertilized at the low $\mathrm{N}$ rate, plants in the thermophilically digested biosolids substrate, Tagro, outperformed the control plants in all measures and Tagro:bark outperformed the control in all but SGI in which they were similar. At the high $\mathrm{N}$ rate, Tagro:bark had more flower buds than controls. Klock-Moore (1999) found substrates containing a biosolids and yard trimmings compost produced significantly larger begonia and impatiens plants than substrates with compost made from recycled greenhouse substrates and yard trimmings. They attributed this to the higher initial nutrient concentrations in substrates containing biosolids and found a significant linear increase in shoot dry mass and size as the component containing biosolids compost increased from $0 \%$ to $100 \%$ in the substrate.

In our experiment, the Groco biosolids compost, although producing plants equivalent to the control at the low $\mathrm{N}$ rate, did not perform as well as Tagro or Tagro:bark (Table 4). At the high $\mathrm{N}$ rate, Groco plants were equivalent to the controls only in SGI and were less desirable than the Tagro or Tagro:bark plants in all four parameters. Although Groco initially had more $\mathrm{NO}_{3}$ - and $\mathrm{NH}_{4}-\mathrm{N}$ than Tagro (Tables 1 and 2), the WHC of Groco at $19 \%$ was less 
Table 4. Effect of growth substrates and nitrogen rates on shoot dry weight, shoot growth index (SGI), shoot quality, and flower bud number of overhead irrigated 'Shasta' chrysanthemum.

\begin{tabular}{|c|c|c|c|c|c|c|c|c|c|c|c|c|}
\hline \multirow[b]{2}{*}{ Substrates } & \multicolumn{3}{|c|}{ Dry wt (g) } & \multicolumn{3}{|c|}{$\mathrm{SGI}^{\mathrm{z}}$} & \multicolumn{3}{|c|}{ Quality $^{\mathrm{y}}$} & \multicolumn{3}{|c|}{ Flower bud number } \\
\hline & High N & Low $\mathrm{N}$ & & High $N$ & Low $\mathrm{N}$ & & High $N$ & Low N & & High N & Low $\mathrm{N}$ & \\
\hline Dairy compost & $10.9 \operatorname{cd}^{\mathrm{x}}$ & $7.4 \mathrm{~d}$ & $* \mathrm{w}$ & $32.5 \mathrm{ab}$ & $26.3 \mathrm{c}$ & $* * *$ & $5.0 \mathrm{a}$ & $3.6 \mathrm{bc}$ & $* * *$ & $23.9 \mathrm{~cd}$ & $13.9 \mathrm{~b}$ & \\
\hline Dairy compost:bark & $12.0 \mathrm{bcd}$ & $7.6 \mathrm{~d}$ & $* * *$ & $33.1 \mathrm{ab}$ & $28.0 \mathrm{c}$ & $* * *$ & $5.0 \mathrm{a}$ & $3.3 \mathrm{c}$ & $* * *$ & $25.1 \mathrm{~cd}$ & $15.3 \mathrm{~b}$ & $* * *$ \\
\hline Dairy fiber & $11.7 \mathrm{~cd}$ & $10.8 \mathrm{bc}$ & NS & $30.7 \mathrm{~b}$ & $28.1 \mathrm{bc}$ & $*$ & $5.0 \mathrm{a}$ & $4.9 \mathrm{a}$ & NS & $23.0 \mathrm{~cd}$ & $18.6 \mathrm{~b}$ & NS \\
\hline Dairy fiber:bark & $12.0 \mathrm{bcd}$ & $7.3 \mathrm{~d}$ & $* * *$ & $32.1 \mathrm{ab}$ & $27.3 \mathrm{c}$ & $* *$ & $5.0 \mathrm{a}$ & $3.6 \mathrm{bc}$ & $* * *$ & $24.5 \mathrm{~cd}$ & $14.0 \mathrm{~b}$ & ** \\
\hline Groco & $9.0 \mathrm{~d}$ & $7.8 \mathrm{~d}$ & NS & $30.4 \mathrm{~b}$ & $28.0 \mathrm{c}$ & $*$ & $4.8 \mathrm{~b}$ & $4.0 \mathrm{~b}$ & $* * *$ & $20.5 \mathrm{~d}$ & $14.8 \mathrm{~b}$ & $* *$ \\
\hline Groco:bark & $12.3 \mathrm{bcd}$ & $7.7 \mathrm{~d}$ & $* * *$ & $32.3 \mathrm{ab}$ & $27.5 \mathrm{c}$ & $* * *$ & $5.0 \mathrm{a}$ & $4.0 \mathrm{~b}$ & $* * *$ & $31.9 \mathrm{abc}$ & $16.1 \mathrm{~b}$ & $* * *$ \\
\hline Tagro & $15.5 \mathrm{ab}$ & $14.2 \mathrm{a}$ & NS & $35.3 \mathrm{a}$ & $32.4 \mathrm{a}$ & $* *$ & $5.0 \mathrm{a}$ & $5.0 \mathrm{a}$ & NS & $36.7 \mathrm{ab}$ & $34.6 \mathrm{a}$ & NS \\
\hline Tagro:bark & $16.1 \mathrm{a}$ & $12.2 \mathrm{ab}$ & $*$ & $34.5 \mathrm{a}$ & $31.0 \mathrm{ab}$ & $*$ & $5.0 \mathrm{a}$ & $5.0 \mathrm{a}$ & NS & $41.0 \mathrm{a}$ & $30.6 \mathrm{a}$ & $* *$ \\
\hline Peat-perlite control & $12.8 \mathrm{abc}$ & $8.9 \mathrm{~cd}$ & $* *$ & $33.3 \mathrm{ab}$ & $28.3 \mathrm{bc}$ & $* * *$ & $5.0 \mathrm{a}$ & $4.0 \mathrm{~b}$ & $* * *$ & $31.3 \mathrm{bc}$ & $18.8 \mathrm{~b}$ & $* * *$ \\
\hline
\end{tabular}

${ }^{\mathrm{z}} \mathrm{SGI}=[$ (widest width + narrowest width $) / 2+$ height $] / 2$.

${ }^{y}$ Shoot quality was rated on a 1 to 5 scale in which $5=$ superior, $1=$ poor, and a rating of 3 was considered marketable.

${ }^{x}$ Means within a column followed by the same letter are not significantly different at the $P=0.05$ level using a protected Tukey's studentized range test.

${ }_{\mathrm{NS}}, * * *, * * *$ indicate nonsignificance or significance at $P=0.05,0.01,0.001$ level, respectively, as determined by Student's $t$ test of the fertilizer effect within a growth substrate treatment.

than Tagro, Tagro:bark, or any of the other substrates (Table 1). Surface-applied water was observed to drain more quickly through Groco potentially leaching nutrients and leading to less water for plant uptake.

Ingram et al. (1990) recommended a substrate WHC of $40 \%$ to $50 \%$ for most greenhouse crops; this same range was recommended for a "universal substrate suitable for most ornamental plants" by Verdonck et al. (1981). The addition of $50 \%$ douglas-fir bark by volume increased the WHC of Groco from $19 \%$ to $40 \%$ (Table 1). In Groco:bark, shoot growth, quality, and flower bud numbers of plants were similar to the peat-perlite controls at both $\mathrm{N}$ rates (Table 4). At the high $\mathrm{N}$ rate, SGI, quality, and flower buds of Groco:bark plants were similar to Tagro and Tagro:bark and dry weight was similar to Tagro.

Within a growth substrate treatment, doubling the amount of $\mathrm{N}$ by applying every second day instead of every fourth day generally increased the dry weight, SGI, quality, and flower bud numbers of overheadirrigatedplants (Table 4). Exceptions where the high $\mathrm{N}$ versus low $\mathrm{N}$ comparisons were not significant occurred with dairy fiber and Tagro dry weight, quality, and flower buds; Tagro: bark quality; and Groco dry weight. These substrates generally had higher initial $\mathrm{NO}_{3}{ }^{-}$, $\mathrm{NH}_{4}-\mathrm{N}$, and total $\mathrm{P}$ than the others (Table 2).

Subirrigation. At the high $\mathrm{N}$ rate, comparison of growth substrates for the subirrigated plants indicated that, with the exception of Groco, shoot dry weight, SGI, quality, and number of flower buds on plants in the experimental substrates were similar to those of plants in the control (Table 5). Subirrigated, high $\mathrm{N}$ plants in Groco were generally smaller with fewer flower buds than plants in the control and all but dairy fiber. Quality of Groco plants, although marketable, was lower than plants in the other substrates. At the low $\mathrm{N}$ rate, dry weight of plants in the experimental substrates did not differ from the controls. SGI and number of flower buds were also similar to the peat-perlite controls in all but the Tagro:bark, Groco, and dairy compost: bark (Table 5). Plants in Tagro:bark had larger SGIs and more flower buds than the controls, whereas Groco plants were the opposite with smaller SGIs and fewer flower buds. Dairy compost:bark plants had fewer flower buds than the controls. Quality of subirrigated low $\mathrm{N}$ plants in dairy compost, dairy fiber:bark, and Groco:bark was similar to the controls. Plants grown in Tagro, Tagro:bark, and dairy fiber were of higher quality than controls, whereas dairy compost:bark and Groco plants were of lower quality.

In this experiment, subirrigated plants grown in the biosolids compost Groco were inferior to peat-perlite control plants in all parameters measured at the high $\mathrm{N}$ rate (Table 5 ) and in all but dry weight at the low $\mathrm{N}$ rate. Like with the overhead-irrigated plants, when douglas-fir bark was added to Groco at $50 \%$ by volume, results were equivalent to the controls in all measured parameters. Subirrigation systems require proper porosity for uptake and retention of water through capillarity. Gabriëls et al. (1986) stressed the importance of substrate physical properties for recirculating subirrigation systems and indicated that particle size distribution, especially in the 0 to 0.5 and 0.5 to $1-\mathrm{mm}$ fractions, is a major factor in determining the air and water relations of a substrate. The percent of fine particles (less than $0.42 \mathrm{~mm}$ ) in Groco was less than the control, Tagro, or Tagro:bark (Table 3). Addition of $50 \%$ douglas-fir bark by volume increased percent fine particles in Groco from $4 \%$ to $10 \%$ (Table 3) improving uptake of water through capillarity.

Doubling the amount of $\mathrm{N}$ did not affect shoot growth and quality parameters of subirrigated chrysanthemums as frequently as overhead-irrigated plants. When $\mathrm{N}$ rate was significant, plants receiving the high rate performed better. Klock-Moore and Broschat (1999) found subirrigated petunias of similar size were produced with one-third the rate of fertilizer as surface-irrigated petunias.

\section{Leaf color}

Measured differences in leaf color across treatments were not large. Differences between $\mathrm{N}$ rates tended to be greater and more frequently significant than differences among substrates, particularly for value ( $\left.\mathrm{L}^{*}\right)$ and chroma $\left(\mathrm{C}^{*}\right)$ (Tables 6 and 7$)$. None of the experimental substrates performed better than the peat-perlite control for any color measurement at either $\mathrm{N}$ level under either irrigation system. Chrysanthemum grown in dairy compost and dairy fiber, with and without bark, tended to have the least desirable leaf colors (Tables 6 and 7), although differences were small.

The substrates that showed the greatest chrysanthemum growth and quality responses to $\mathrm{N}$ rate under subirrigation (dairy compost, dairy compost:bark, dairy fiber:bark, and the peat-perlite control) also showed the greatest color response to $\mathrm{N}$ rate (Table 7). The same was true for plants grown with overhead irrigation (Table 6). Chrysanthemum grown in Groco alone showed little color response to $\mathrm{N}$ rate, indicating that the poorer plant performance in Groco was not caused by a lack of $\mathrm{N}$. Although there were some small differences in leaf color, visual quality ratings and growth measurements indicated that both subirrigated and surface-irrigated chrysanthemums in all substrates were marketable.

Leaf greenness response of Salvia genotypes to a biosolids-yard trimmings compost, a commercial peat-perlite-vermiculite substrate, and a 1:1 combination of the two using surface or subirrigation systems varied with genotype (Wilson et al., 2003). Salvia 'Indigo Spires' leaf greenness was not influenced by substrate or irrigation system, Salvia 'Van Houttei' was influenced by substrate but not irrigation system, whereas there was a significant irrigation system by substrate interaction for $S$. gauranitica. Results of whole plant visual quality and growth measurements indicated all substrates and irrigation systems produced marketable plants for each salvia genotype with the single exception of 'Van Houttei' in 50\% compost using drip irrigation. Wilson et al. (2003) concluded biosolids-yardwaste compost could serve as a complete or partial substitute for peat in commercial substrates used to produce containerized perennial plants using ebb and flow, manual, or drip irrigation systems.

\section{Root growth}

In both irrigation systems, roots of plants in the experimental substrates were similar to the control plants for all measured parameters: root dry weight, root length, and root density (data not shown). Root length as measured by rating the length of roots visible at the periphery of the root ball was unaffected 
Table 5. Effect of growth substrates and nitrogen rates on shoot dry weight, shoot growth index (SGI), shoot quality, and flower bud number of subirrigated 'Shasta' chrysanthemum.

\begin{tabular}{|c|c|c|c|c|c|c|c|c|c|c|c|c|}
\hline \multirow[b]{2}{*}{ Substrates } & \multicolumn{3}{|c|}{ Dry wt $(\mathrm{g})$} & \multicolumn{3}{|c|}{$\mathrm{SGI}^{2}$} & \multicolumn{3}{|c|}{ Quality $^{y}$} & \multicolumn{3}{|c|}{ Flower bud number } \\
\hline & High $\mathrm{N}$ & Low $\mathrm{N}$ & & High $\mathrm{N}$ & Low N & & High N & Low $\mathrm{N}$ & & High N & Low $\mathrm{N}$ & \\
\hline Dairy compost:bark & $13.6 \mathrm{a}$ & $8.1 \mathrm{~b}$ & $* * *$ & $36.7 \mathrm{a}$ & $32.1 \mathrm{~cd}$ & ** & $5.0 \mathrm{a}$ & $3.4 \mathrm{c}$ & $* * *$ & $27.9 \mathrm{ab}$ & $13.5 \mathrm{~d}$ & *** \\
\hline Groco & $7.1 \mathrm{~b}$ & $6.8 \mathrm{~b}$ & NS & $30.4 \mathrm{~b}$ & $31.0 \mathrm{~d}$ & NS & $3.8 \mathrm{~b}$ & $3.4 \mathrm{c}$ & NS & $12.6 \mathrm{c}$ & $12.0 \mathrm{~d}$ & NS \\
\hline Groco:bark & $12.7 \mathrm{a}$ & $10.8 \mathrm{ab}$ & NS & $35.3 \mathrm{a}$ & $32.8 \mathrm{bcd}$ & ** & $5.0 \mathrm{a}$ & $4.4 \mathrm{ab}$ & ** & $28.8 \mathrm{ab}$ & $22.0 \mathrm{bc}$ & NS \\
\hline Tagro & $13.9 \mathrm{a}$ & $13.9 \mathrm{ab}$ & NS & $35.4 \mathrm{a}$ & $34.8 \mathrm{ab}$ & NS & $5.0 \mathrm{a}$ & $5.0 \mathrm{a}$ & NS & $27.9 \mathrm{ab}$ & $28.5 \mathrm{~b}$ & NS \\
\hline
\end{tabular}

${ }^{\mathrm{z}} \mathrm{SGI}=[($ widest width + narrowest width $) / 2+$ height $] / 2$.

${ }^{y}$ Shoot quality was rated on a 1 to 5 scale in which $5=$ superior, $1=$ poor, and a rating of 3 was considered marketable.

'Means within a column followed by the same letter are not significantly different at the $P=0.05$ level using a protected Tukey's studentized range test.

${ }^{\mathrm{N}} \mathrm{NS},{ }^{*}, * *, * * *$ indicate nonsignificance or significance at $P=0.05,0.01,0.001$ level, respectively, as determined by Student's $t$ test of the fertilizer effect within a growth substrate treatment.

Table 6. Effect of growth substrates and nitrogen rates on the leaf color characteristics of lightness ( $\left.\mathrm{L}^{*}\right)$, hue angle, and chroma of overhead irrigated 'Shasta' chrysanthemum.

\begin{tabular}{|c|c|c|c|c|c|c|c|c|c|}
\hline \multirow[b]{2}{*}{ Substrates } & \multicolumn{3}{|c|}{$\mathrm{L}^{* \mathrm{z}}$} & \multicolumn{3}{|c|}{ Hue angle ${ }^{y}$} & \multicolumn{3}{|c|}{ Chroma $^{\mathrm{x}}$} \\
\hline & High $N$ & Low $\mathrm{N}$ & & High $N$ & Low N & & High $N$ & Low $\mathrm{N}$ & \\
\hline Dairy compost & $39.59 \mathrm{ab}^{\mathrm{w}}$ & $41.69 \mathrm{a}$ & $* * * v$ & $127.48 \mathrm{ab}$ & $127.92 \mathrm{a}$ & NS & $25.26 \mathrm{ab}$ & $27.27 \mathrm{a}$ & $* *$ \\
\hline Dairy compost:bark & $40.26 \mathrm{a}$ & $42.11 \mathrm{a}$ & $* *$ & $127.08 \mathrm{ab}$ & $127.89 \mathrm{a}$ & NS & $25.80 \mathrm{a}$ & $27.85 \mathrm{a}$ & $* *$ \\
\hline Dairy fiber & $39.55 \mathrm{ab}$ & $40.25 \mathrm{ab}$ & NS & $126.62 \mathrm{~b}$ & $127.24 \mathrm{a}$ & NS & $25.09 \mathrm{ab}$ & $26.62 \mathrm{ab}$ & NS \\
\hline Dairy fiber:bark & $40.04 \mathrm{a}$ & $41.68 \mathrm{a}$ & $*$ & $127.35 \mathrm{ab}$ & $127.05 \mathrm{a}$ & NS & $25.52 \mathrm{a}$ & $27.74 \mathrm{a}$ & $*$ \\
\hline Groco & $39.22 \mathrm{ab}$ & $40.46 \mathrm{ab}$ & NS & $126.57 \mathrm{~b}$ & $127.50 \mathrm{a}$ & $*$ & $24.99 \mathrm{ab}$ & $26.14 \mathrm{ab}$ & NS \\
\hline Groco:bark & $39.63 \mathrm{ab}$ & $41.59 \mathrm{a}$ & $* * *$ & $127.56 \mathrm{ab}$ & $127.29 \mathrm{a}$ & NS & $24.99 \mathrm{ab}$ & $27.97 \mathrm{a}$ & $* * *$ \\
\hline Tagro & $38.86 \mathrm{ab}$ & $39.05 \mathrm{~b}$ & NS & $127.03 \mathrm{ab}$ & $127.33 \mathrm{a}$ & NS & $23.79 \mathrm{ab}$ & $24.47 \mathrm{~b}$ & NS \\
\hline Tagro:bark & $39.34 \mathrm{ab}$ & $40.81 \mathrm{ab}$ & $*$ & $126.97 \mathrm{~b}$ & $127.67 \mathrm{a}$ & NS & $24.79 \mathrm{ab}$ & $26.76 \mathrm{ab}$ & $*$ \\
\hline Peat-perlite control & $38.43 \mathrm{~b}$ & $40.51 \mathrm{ab}$ & $* * *$ & $128.66 \mathrm{a}$ & $128.41 \mathrm{a}$ & NS & $23.10 \mathrm{~b}$ & $26.00 \mathrm{ab}$ & $* * *$ \\
\hline
\end{tabular}

${ }^{\mathrm{z}} \mathrm{L} *$ is the color lightness or value $0=$ black to $100=$ white.

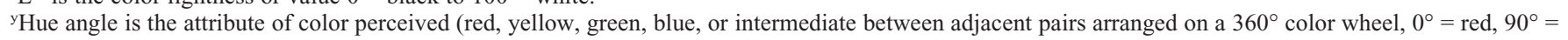
yellow, $180^{\circ}=$ green, and $270^{\circ}=$ blue).

${ }^{\mathrm{x}}$ Chroma is the degree of color from gray (0) to pure chromatic color.

wMeans within a column followed by the same letter are not significantly different at the $P=0.05$ level using a protected Tukey's studentized range test.

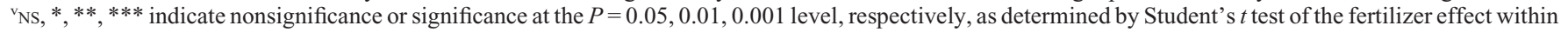
a growth substrate treatment.

Table 7. Effect of growth substrates and nitrogen rates on the leaf color characteristics of lightness (L*), hue angle, and chroma of subirrigated 'Shasta' chrysanthemum.

\begin{tabular}{|c|c|c|c|c|c|c|c|c|c|}
\hline \multirow[b]{2}{*}{ Substrates } & \multicolumn{3}{|c|}{$\mathrm{L}^{* \mathrm{z}}$} & \multicolumn{3}{|c|}{ Hue angle ${ }^{y}$} & \multicolumn{3}{|c|}{ Chroma $^{\mathrm{x}}$} \\
\hline & High N & Low $\mathrm{N}$ & & High N & Low N & & High N & Low $\mathrm{N}$ & \\
\hline Dairy compost:bark & $40.51 \mathrm{a}$ & $43.38 \mathrm{a}$ & $* * *$ & $127.36 \mathrm{a}$ & $125.67 \mathrm{~b}$ & $*$ & $24.41 \mathrm{ab}$ & $29.40 \mathrm{a}$ & $* * *$ \\
\hline Dairy fiber:bark & $39.86 \mathrm{a}$ & $42.36 \mathrm{abc}$ & $* * *$ & $127.52 \mathrm{a}$ & $126.32 \mathrm{ab}$ & NS & $24.07 \mathrm{ab}$ & $28.17 \mathrm{ab}$ & $* * *$ \\
\hline Groco & $41.03 \mathrm{a}$ & $41.78 \mathrm{bc}$ & NS & $126.98 \mathrm{a}$ & $126.85 \mathrm{ab}$ & NS & $25.04 \mathrm{ab}$ & $26.86 \mathrm{bc}$ & $*$ \\
\hline Groco:bark & $39.44 \mathrm{a}$ & $41.39 \mathrm{~cd}$ & $* * *$ & $128.26 \mathrm{a}$ & $127.57 \mathrm{ab}$ & NS & $23.66 \mathrm{~b}$ & $26.88 \mathrm{bc}$ & $* * *$ \\
\hline Tagro & $39.65 \mathrm{a}$ & $40.29 \mathrm{~d}$ & NS & $128.37 \mathrm{a}$ & $126.80 \mathrm{ab}$ & ** & $22.95 \mathrm{~b}$ & $24.34 \mathrm{~d}$ & * \\
\hline
\end{tabular}

${ }^{\mathrm{z}} \mathrm{L}^{*}$ is the color lightness or value $0=$ black to $100=$ white.

${ }^{\mathrm{y}} \mathrm{Hue}$ angle is the attribute of color perceived (red, yellow, green, blue, or intermediate between adjacent pairs arranged on a $360^{\circ}$ color wheel, $0^{\circ}=$ red, $90^{\circ}=$ yellow, $180^{\circ}=$ green, and $270^{\circ}=$ blue).

${ }^{\mathrm{x}}$ Chroma is the degree of color from gray $(0)$ to pure chromatic color.

wMeans within a column followed by the same letter are not significantly different at the $P=0.05$ level using a protected Tukey's studentized range test.

${ }^{\vee} \mathrm{NS}, * * *, * * *$ indicate nonsignificance or significance at $P=0.05,0.01,0.001$ level, respectively, as determined by Student's $t$ test of the fertilizer rates within a growth substrate treatment.

by $\mathrm{N}$ rate in either irrigation system. Roots of plants in all treatments grew to circle the container bottoms.

There was little effect of $\mathrm{N}$ rate on density of roots at the periphery of the root ball; for all plants in this experiment, density was rated as either a 3 (many roots visible but growth substrate still obvious) or a 4 (solid root mass with little or no growth substrate visible). N rate produced a significant root density effect only on subirrigated plants in Tagro:bark in which roots of low $\mathrm{N}$ plants were rated more dense than roots of high $\mathrm{N}$ plants. In overheadirrigated plants, $\mathrm{N}$ rate affected only plants in dairy compost:bark in which root density of high $\mathrm{N}$ plants was greater than low $\mathrm{N}$ plants (data not shown).

Root dry weight of overhead-irrigated plants was influenced by $\mathrm{N}$ rate only in the dairy fiber:bark substrate in which root weight of high $\mathrm{N}$ plants increased. In the subirrigation system, $\mathrm{N}$ rate influenced root dry weight in two substrates: in dairy fiber:bark and the peatperlite control; both had larger roots in the low $\mathrm{N}$ fertilizer treatment (data not shown).

Results of this experiment show little effect of $\mathrm{N}$ rate on root growth of chrysanthemum. When $\mathrm{N}$ rate was significant, roots of subirrigated plants grew better at the low $\mathrm{N}$ rate, whereas roots of overhead-irrigated 
plants grew better at the high $\mathrm{N}$ rate. This result perhaps reflects the general recommendation for soluble fertilizer in subirrigation systems - use one-half the concentration used in overhead or drip irrigation systems (Reed, 1996).

\section{Leachate}

Nitrate-N levels declined with time for both irrigation systems and both $\mathrm{N}$ fertilization schedules (Tables 8 and 9). Overall, nitrate-N was greater in leachate from the high $\mathrm{N}$ fertilization schedule. Mean nitrate-N levels averaged over all substrates remained above $10 \mathrm{mg} \cdot \mathrm{L}^{-1}$ through the first 6 weeks after transplant for the high $\mathrm{N}$ treatment under subirrigation, whereas mean nitrate levels dropped below $10 \mathrm{mg} \cdot \mathrm{L}^{-1}$ by the fourth week after transplant for the other $\mathrm{N}$ rate-irrigation combinations. Because water is not lost to leaching in recirculating subirrigated systems, higher nitrate-N levels do not indicate a greater risk of nitrate leaching, but rather conservation of nitrate within the system. The differences in leachate nitrate-N content in different substrates were small and inconsistent. When the experimental substrates were mixed with bark, nitrate-N levels were always equal to or less than for the peat-perlite control. Nitrate-N levels in substrates not mixed with bark were

Table 8. Effect of growth substrates and nitrogen rates on nitrate nitrogen in leachate collected from overhead irrigated 'Shasta' chrysanthemum at 2-week intervals after transplant (WAT).

\begin{tabular}{|c|c|c|c|c|}
\hline \multirow[b]{2}{*}{ Substrates } & $\begin{array}{l}2 \text { WAT } \\
\text { High N }\end{array}$ & $\begin{array}{l}4 \text { WAT } \\
\text { High N }\end{array}$ & $\begin{array}{l}6 \text { WAT } \\
\text { High N }\end{array}$ & $\begin{array}{l}8 \text { WAT } \\
\text { High N }\end{array}$ \\
\hline & \multicolumn{4}{|c|}{---------------------------------------- mg.L'-1 -------------------------------------- } \\
\hline Dairy compost & $14 a b c^{z}$ & $1 \mathrm{c}$ & $5 \mathrm{a}$ & $1 \mathrm{a}$ \\
\hline Dairy compost:bark & $7 \mathrm{c}$ & $2 \mathrm{bc}$ & $5 \mathrm{a}$ & $1 \mathrm{a}$ \\
\hline Dairy fiber & $38 \mathrm{ab}$ & $12 \mathrm{ab}$ & $4 \mathrm{a}$ & $1 \mathrm{a}$ \\
\hline Dairy fiber:bark & $8 \mathrm{bc}$ & $1 \mathrm{c}$ & 4 a & $1 \mathrm{a}$ \\
\hline Groco & $40 \mathrm{a}$ & $9 \mathrm{bc}$ & $11 \mathrm{a}$ & $1 \mathrm{a}$ \\
\hline Groco:bark & $24 a b c$ & $2 \mathrm{bc}$ & $4 \mathrm{a}$ & $1 \mathrm{a}$ \\
\hline Tagro & $27 \mathrm{abc}$ & $23 \mathrm{a}$ & $4 \mathrm{a}$ & $1 \mathrm{a}$ \\
\hline Tagro:bark & $14 a b c$ & $9 \mathrm{bc}$ & $4 \mathrm{a}$ & $1 \mathrm{a}$ \\
\hline \multirow[t]{3}{*}{ Peat-perlite control } & $43 \mathrm{a}$ & $1 \mathrm{c}$ & 3 a & $1 \mathrm{a}$ \\
\hline & Low N & Low $\mathrm{N}$ & Low N & Low N \\
\hline & \multicolumn{4}{|c|}{ 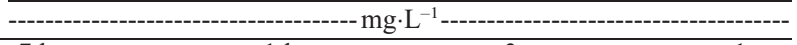 } \\
\hline Dairy compost & $7 \mathrm{bc}$ & $1 \mathrm{~b}$ & $3 \mathrm{a}$ & $1 \mathrm{a}$ \\
\hline Dairy compost:bark & $3 \mathrm{c}$ & $1 \mathrm{~b}$ & 4 a & $1 \mathrm{a}$ \\
\hline Dairy fiber & $28 \mathrm{a}$ & $3 a b$ & 4 a & $1 \mathrm{a}$ \\
\hline Dairy fiber:bark & $4 \mathrm{c}$ & $1 \mathrm{~b}$ & $2 \mathrm{a}$ & $1 \mathrm{a}$ \\
\hline Groco & $18 \mathrm{ab}$ & $2 \mathrm{~b}$ & $9 \mathrm{a}$ & $1 \mathrm{a}$ \\
\hline Groco:bark & $13 \mathrm{bc}$ & $1 \mathrm{~b}$ & $7 \mathrm{a}$ & $1 \mathrm{a}$ \\
\hline Tagro & $14 \mathrm{bc}$ & $6 \mathrm{a}$ & $8 \mathrm{a}$ & $1 \mathrm{a}$ \\
\hline Tagro:bark & $12 \mathrm{bc}$ & $3 a b$ & $8 \mathrm{a}$ & $1 \mathrm{a}$ \\
\hline Peat-perlite control & $4 \mathrm{c}$ & $1 \mathrm{~b}$ & $3 \mathrm{a}$ & $1 \mathrm{a}$ \\
\hline
\end{tabular}

${ }^{\mathrm{z}}$ Means within a column followed by the same letter are not significantly different at the $P=0.05$ level using a protected Tukey's Studentized range test.

Table 9. Effect of growth substrates and nitrogen rates on nitrate nitrogen in leachate collected from subirrigated 'Shasta' chrysanthemum at 2-week intervals after transplant (WAT).

\begin{tabular}{|c|c|c|c|c|}
\hline \multirow[b]{2}{*}{ Substrates } & $\begin{array}{l}2 \text { WAT } \\
\text { High N }\end{array}$ & $\begin{array}{l}\text { 4 WAT } \\
\text { High N }\end{array}$ & $\begin{array}{l}6 \text { WAT } \\
\text { High N }\end{array}$ & $\begin{array}{l}8 \text { WAT } \\
\text { High N }\end{array}$ \\
\hline & \multicolumn{4}{|c|}{ 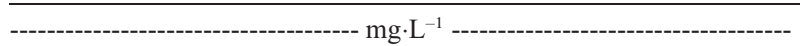 } \\
\hline Dairy compost & $25 b^{z}$ & $7 \mathrm{a}$ & $3 \mathrm{~b}$ & $1 \mathrm{~b}$ \\
\hline Dairy compost:bark & $12 \mathrm{~b}$ & $8 \mathrm{a}$ & $7 \mathrm{ab}$ & $1 \mathrm{~b}$ \\
\hline Dairy fiber & $19 \mathrm{~b}$ & $20 \mathrm{a}$ & $20 \mathrm{ab}$ & $11 \mathrm{a}$ \\
\hline Dairy fiber:bark & $23 \mathrm{~b}$ & $5 \mathrm{a}$ & $8 \mathrm{ab}$ & $1 \mathrm{~b}$ \\
\hline Groco & $16 \mathrm{~b}$ & $9 \mathrm{a}$ & $15 \mathrm{ab}$ & $3 \mathrm{~b}$ \\
\hline Groco:bark & $19 \mathrm{~b}$ & $6 \mathrm{a}$ & $11 \mathrm{ab}$ & $1 \mathrm{~b}$ \\
\hline Tagro & $13 \mathrm{~b}$ & $6 \mathrm{a}$ & $24 \mathrm{a}$ & $2 \mathrm{~b}$ \\
\hline Tagro:bark & $12 \mathrm{~b}$ & $14 \mathrm{a}$ & $17 \mathrm{ab}$ & $1 \mathrm{~b}$ \\
\hline \multirow[t]{3}{*}{ Peat-perlite control } & $58 \mathrm{a}$ & $21 \mathrm{a}$ & $18 \mathrm{ab}$ & $1 \mathrm{~b}$ \\
\hline & Low $\mathrm{N}$ & Low $\mathrm{N}$ & Low $\mathrm{N}$ & Low $\mathrm{N}$ \\
\hline & \multicolumn{4}{|c|}{ 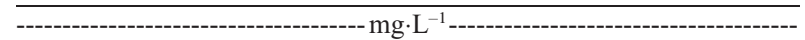 } \\
\hline Dairy compost & $5 \mathrm{bc}$ & $1 \mathrm{~b}$ & $1 \mathrm{~b}$ & $1 \mathrm{a}$ \\
\hline Dairy compost:bark & $4 \mathrm{bc}$ & $1 \mathrm{~b}$ & $1 \mathrm{~b}$ & $1 \mathrm{a}$ \\
\hline Dairy fiber & $12 \mathrm{ab}$ & $9 \mathrm{a}$ & $2 \mathrm{a}$ & $1 \mathrm{a}$ \\
\hline Dairy fiber:bark & $5 \mathrm{bc}$ & $1 \mathrm{~b}$ & $1 \mathrm{~b}$ & $1 \mathrm{a}$ \\
\hline Groco & $8 \mathrm{bc}$ & $1 \mathrm{~b}$ & $1 \mathrm{~b}$ & $1 \mathrm{a}$ \\
\hline Groco:bark & $5 \mathrm{bc}$ & $1 \mathrm{~b}$ & $1 \mathrm{~b}$ & $1 \mathrm{a}$ \\
\hline Tagro & $3 c$ & $1 \mathrm{~b}$ & $1 \mathrm{~b}$ & $1 \mathrm{a}$ \\
\hline Tagro:bark & $4 \mathrm{bc}$ & $1 \mathrm{~b}$ & $1 \mathrm{~b}$ & $1 \mathrm{a}$ \\
\hline Peat-perlite control & $20 \mathrm{a}$ & $1 \mathrm{~b}$ & $1 \mathrm{~b}$ & $1 \mathrm{a}$ \\
\hline
\end{tabular}

${ }^{\mathrm{z}}$ Means within a column followed by the same letter are not significantly different at the $P=0.05$ level using a protected Tukey's Studentized range test. occasionally higher than for the control. The results show that the experimental substrates mixed with bark do not increase nitrate-N loss under greenhouse production conditions.

All values for EC for leachate were less than $1.5 \mathrm{dS} \cdot \mathrm{m}^{-1}$ and declined with time. EC ranged from 0.5 to $1.4 \mathrm{dS} \cdot \mathrm{m}^{-1}$ for the first leaching and 0.1 to $0.6 \mathrm{dS} \cdot \mathrm{m}^{-1}$ at the final leaching. There were few significant effects of $\mathrm{N}$ rate on $\mathrm{EC}$ and no consistent differences among substrates (data not shown).

Williams and Nelson (1992) surface-irrigated chrysanthemum 'Sunny Mandalay' with a leaching fraction averaging 0.75 and found organic sources released $\mathrm{N}$ most rapidly during the first 2 weeks of production followed by a decline, which ended after 6 to 7 weeks. In their study, dried, anaerobically digested poultry manure sludge, although an inefficient $\mathrm{N}$ source, was an effective organic $\mathrm{P}$ fertilizer. Broschat (2008) found granular pasteurized poultry litter provided significant amounts of $\mathrm{N}, \mathrm{P}, \mathrm{K}$, manganese, and zinc for plant growth, but most nutrient release occurred during the first few weeks after potting; plants were grown outdoors under overhead irrigation plus natural rainfall. Recirculating subirrigation systems have the potential to capture and use nutrients from organic waste-based substrates (Giles et al., 2005) thus enhancing the sustainability of container production operations.

Target $\mathrm{pH}$ for potting substrates varies somewhat with plant species but for most crops, a range of 5.0 or 5.5 to 6.5 reduces the risk of $\mathrm{pH}$-related micronutrient deficiencies or toxicities (Ingram et al., 1990). Initial pH and leachate $\mathrm{pH}$ for dairy compost, dairy fiber, and dairy fiber:bark exceeded 6.5 throughout the course of the study (Tables 1 and 10). Mixing dairy compost with bark brought the initial $\mathrm{pH}$ into the acceptable range (Table 1) and the leachate $\mathrm{pH}$ was also acceptable (Table 10). Groco, Groco:bark, Tagro, and Tagro:bark (all biosolids-based substrates) had $\mathrm{pH}$ lower than or equal to the peat-perlite control, but all were within the target $\mathrm{pH}$ range (Tables 1 and 10). Leachate $\mathrm{pH}$ tended to be lower than the $\mathrm{pH}$ measured in the initial substrate pour-through tests before potting (Table 1). $\mathrm{N}$ fertilization regime had little effect on $\mathrm{pH}$ (data not shown).

\section{Summary}

This research demonstrated the successful replacement of peat-perlite with container growth substrates made with recycled organic materials. Most of the experimental substrates produced plants of equal or better quality than

Table 10. Mean $\mathrm{pH}$ of substrates averaged over four sampling dates and two $\mathrm{N}$ rates.

\begin{tabular}{ll}
\hline Dairy compost & 7.2 \\
Dairy compost:bark & 6.2 \\
Dairy fiber & 7.2 \\
Dairy fiber:bark & 7.0 \\
Groco & 5.7 \\
Groco:bark & 5.8 \\
Tagro & 6.3 \\
Tagro:bark & 5.9 \\
Peat-perlite control & 6.5 \\
\hline
\end{tabular}


the peat-perlite for both overhead-irrigated and subirrigated management. Particle size was critical, because the Groco biosolids compost had fewer fines and lower water-holding capacity and produced the least growth and poorest quality of plants. Addition of bark to Groco reduced the particle size problem. The Tagro biosolids-based materials performed well, particularly under low $\mathrm{N}$ fertilization, with particle size similar to the peat:perlite, acceptable $\mathrm{pH}$ and EC, and slow-release $\mathrm{N}$ from the biosolids supplementing the fertilizer $\mathrm{N}$. Leaching loss of nitrate from the alternative substrates was similar to the peat-perlite control, and EC of the leachates was low, indicating no negative effects of the alternative substrates on water quality. $\mathrm{N}$ rate had a greater effect than substrate on leachate water quality. Growers adopting alternative substrates as a component of their management can increase the sustainability of their container crop production systems.

Once the technical aspects of container substrate production from recycled organic materials are mastered and facilities are producing consistent quality materials that meet the requirements for plant growth, there remains the question of consumer acceptance. This question is especially pertinent to biosolids-based substrates. However, attitudes are changing. Based on the results of this research, the Tagro:bark mix produced in our study was adapted by the City of Tacoma, WA, and is now sold in bulk and bags as Tagro Potting Soil, a commercial mix for use in pots, containers, and raised beds (City of Tacoma, 2010). Tagro Potting Soil has been manufactured since 2004, and production in 2009 was 3800 yards using $25 \%$ of the total biosolids output from the city.

\section{Literature Cited}

Argo, W.R. and J.A. Biernbaum. 1995. The effect of irrigation method, water-soluble fertilization, preplant nutrient charge, and surface evaporation on early vegetative and root growth of poinsettia. J. Amer. Soc. Hort. Sci. 120:163-169.

Biernbaum, J.A. 1992. Root-zone management of greenhouse container-grown crops to control water and fertilizer use. HortTechnology 2:127132.

Boyer, C.R., C.H. Gilliam, G.B. Fain, T.V. Gallagher, H.A. Torbert, and J.L. Sibley. 2009. Production of woody nursery crops in clean chip residual substrate. J. Environ. Hort. 27:56-62.

Broschat, T.K. 2008. Effectiveness of pasteurized poultry litter as a partial substitute for controlled-release fertilizers in the production of container-grown ornamental plants. HortTechnology 18:671-677.

Buamscha, M.G., J.E. Altland, D.M. Sullivan, D.A. Horneck, and J. Cassidy. 2007. Chemical and physical properties of douglas fir bark relevant to the production of container plants. HortScience 42:1281-1286.

Bugbee, G.J. 2002. Growth of ornamental plants in container media amended with biosolids compost. Compost Sci. Util. 10:92-98.

Carlile, W.R. 2008. The use of composted materials in growing media. Acta Hort. 779:321327.

Chen, Y., Y. Inbar, M. Raviv, and A. Dovrat. 1983. The use of slurry produced by methanogenic fermentation of cow manure as a peat substitute in horticulture-Physical and chemical characteristics. Acta Hort. 150:553-561.

City of Tacoma. 2010. Tagro potting soil. 5 May 2010. <http://www.cityoftacoma.org/Page.aspx? hid $=708>$.

Clark, S. and M. Cavigelli. 2005. Suitability of composts as potting media for production of organic vegetable transplants. Compost Sci. Util. 13:150-156.

Corti, C., L. Crippa, P.L. Genevini, and M. Centemero. 1998. Compost use in plant nurseries: Hydrological and physicochemical characteristics. Compost Sci. Util. 6:35-45.

Estévez-Schwarz, I., S. Seoane, A. Núñez, and M.E. López-Mosquera. 2009. Characterization and evaluation of compost utilized as ornamental plant substrate. Compost Sci. Util. 17:210219.

Evans, M.R. 2004. Processed poultry feather fiber as an alternative to peat in greenhouse crops substrates. HortTechology. 14:176-179.

Evans, M.R. and M. Gachukia. 2004. Fresh parboiled rice hulls serve as an alternative to perlite in greenhouse crop substrates. HortScience 39:232-235.

Fain, G.B., C.H. Gilliam, J.L. Sibley, C.R. Boyer, and A.L. Witcher. 2008. Whole tree substrate and fertilizer rate in production of greenhousegrown petunia (Petunia $\times$ hybrid Vilm.) and marigold (Tagetes patula L.). HortScience 43 : 700-705.

Fitzpatrick, G.E. 2001. Compost utilization in ornamental and nursery crop production systems, p. 135-150. In: Stoffella, P.J. and B.A Kahn (eds.). Compost utilization in horticultural cropping systems. Lewis, Boca Raton, FL.

Gabriëls, R., O. Verdonck, and O. Mekers. 1986. Substrate requirements for pot plants in recirculating water culture. Acta Hort. 178:93-99.

Giles, J., C. Chong, and G. Lumis. 2005. Response of container-grown ninebark to crude and nutrient-enriched recirculating compost leachates. HortScience 40:1507-1512.

Grigatti, M., M.E. Giorgioni, and C. Ciavatta. 2007. Compost-based growing media: Influence on growth and nutrient use of bedding plants. Bioresour. Technol. 98:3526-3534.

Hummel, R.L., C.R. Johnson, R. Riley, and S Smith. 2001. Yard trimmings compost as a growing medium component and nutrient source for chrysanthemum and fuchsia production. Comb. Proc. Int. Plant Prop. Soc. 51:295-299.

Hummel, R.L., S. Kuo, D. Winters, and E.J. Jellum. 2000. Fishwaste compost medium improves growth and quality of container-grown marigolds and geraniums without leaching. J. Environ. Hort. 18:93-98.

Inbar, Y., Y. Chen, and Y. Hadar. 1985. The use of composted slurry produced by methanogenic fermentation of cow manure as a growth media. Acta Hort. 172:75-82.

Ingelmo, F., R. Canet, M.A. Ibanez, F. Pomares, and J. Garcia. 1998. Use of MSW compost, dried sewage sludge and other wastes as partial substitutes for peat and soil. Bioresour. Technol. 63:123-129.

Ingram, D.L., R.W. Henley, and T.H. Yeager 1990. Diagnostic and monitoring procedures for nursery crops. Univ. of Fla. Coop. Extn. Serv. Circ. 556

Jackson, B.E. and R.D. Wright. 2009. Pine tree substrate: An alternative and renewable substrate for horticultural crop production. Acta Hort. 819:265-272.

Kahtz, A.W. and N.J. Gawel. 2004. Growth of barberry liners in media amended with noncomposted recycled waste. HortTechnology 14: 192-195.
Klock-Moore, K.A. 1999. Bedding plant growth in greenhouse waste and biosolid compost. HortTechnology 9:210-213.

Klock-Moore, K.A. and T.K. Broschat. 1999. Differences in bedding plant growth and nitrate loss with a controlled-release fertilizer and two irrigation systems. HortTechnology 9:206-209.

Lu, W., J.L. Sibley, C.H. Gilliam, J.S. Bannon, and Y. Zhang. 2006. Estimation of U.S. bark generation and implications for horticultural industries. J. Environ. Hort. 24:29-34.

McGuire, R.G. 1992. Reporting of objective color measurements. HortScience 27:1254-1255.

Molitor, H.D. 1990. The European perspective with emphasis on subirrigation and recirculation of water and nutrients. Acta Hort. 272:165-173.

Morvant, J.K., J.M. Dole, and J.C. Cole. 1998 Irrigation frequency and system affect poinsettia growth, water use, and runoff. HortScience $33: 42-46$

Morvant, J.K., J.M. Dole, and J.C. Cole. 2001. Fertilizer source and irrigation system affect geranium growth and nitrogen retention. HortScience 36:1022-1026.

Neal, C.A. and R.W. Henley. 1992. Water use and runoff comparisons of greenhouse irrigation systems. Proc. Fla. State Hort. Soc. 105:191-194.

Ozores-Hampton, M., C.S. Vavrina, and T.A. Obreza. 1999. Yard trimming-biosolid compost: Possible alternative to sphagnum peat moss in tomato transplant production. Compost Sci. Util. 7:42-49.

Raviv, M. 2005. Production of high-quality composts for horticultural purposes: A mini-review. HortTechnology 15:52-57.

Reed, D.W. 1996. Closed production systems for containerized crops: Recirculating subirrigation and zero-leach systems, p. 221-245. In: Reed, D.W. (ed.). Water, media and nutrition for greenhouse crops. Ball Publishing, Batavia, IL.

Schmilewski, G.K. 1983. Aspects of the raw material peat-Resources and availability. Acta Hort. 150: 601-610.

Stamps, R.H. and M.R. Evans. 1999. Growth of Dracaena marginata and Spathiphyllum 'Petite' in sphagnum peat- and coconut coir dust-based growing media. J. Environ. Hort. 17:49-52.

Thompson, W.H., P.B. Leege, P.D. Millner, and M.E. Watson. 2001. Test methods for the examination of composting and compost. USDA, Washington, DC

Tittarelli, F., E. Rea, V. Verrastro, J.A. Pasucal, S Canali, F.G. Ceglie, A. Trinchera, and C.M. Rivera. 2009. Compost-based nursery substrates: Effect of peat substitution on organic melon seedlings. Compost Sci. Util. 17:220-228.

U.S. Environmental Protection Agency. 1994. A plain English guide to the EPA Part 503 biosolids rule. EPA/832/R-93/003

Uva, W.L., T.C. Weiler, and R.A. Milligan. 1998. A survey on the planning and adoption of zero runoff subirrigation systems in greenhouse operations. HortScience 33:193-196.

Verdonck, O., D. De Vleeschauwer, and M. De Boodt. 1981. The influence of the substrate to plant growth. Acta Hort. 126:251-258.

Williams, K.A. and P.V. Nelson. 1992. Low, controlled nutrient availability provided by organic waste materials for chrysanthemum. J. Amer. Soc. Hort. Sci. 117:422-429.

Wilson, S.B., P.J. Stoffella, and D.A. Graetz. 2003. Compost amended media and irrigation system influence containerized perennial Salvia. J. Amer. Soc. Hort. Sci. 128:260-268.

Wright, R.D. 1986. The pour-through nutrient extraction procedure. HortScience 21:227-229.

Yoder Brothers, Inc. 1999. Pot chrysanthemum grower's guide. Yoder Brothers, Inc., Barberton, $\mathrm{OH}$ 